\title{
Corrosionfracture kinetics in welded pipes in chlorine-saturated carbon dioxide oilfield media
}

\author{
Anna Fedotova ${ }^{2 *}$, Mikhail Vyboischik ${ }^{1}$, Dmitry Kazdayev², Sergey Knyazkin ${ }^{2}$, Tamara Tetyueva $^{2}$ \\ ${ }^{1}$ Togliatti State University, 445000, Togliatti, Russian Federation \\ ${ }^{2}$ IT-Service LLC, 443001, Samara, Russian Federation
}

\begin{abstract}
Bypass tests of $\varnothing 219 \times 8 \mathrm{~mm} 13 \mathrm{KhFA}, 08 \mathrm{KhMFChA}, 20$-ksh (steel 20 corrosion resistant cold resistant) and Grade steel 20 piping spools were carried out on an oil-gathering line of one of the oilfields in the Stavropol region. Tubing condition was checked after 7, 15, 17 and 23 months of testing. After two years in service no change was found in mechanical properties of the base metal or weldments manufactured from $13 \mathrm{KhFA}$ and $08 \mathrm{KhMFChA}$ steels. It has been demonstrated that the formation of chromium-containing phase in corrosion products inhibits the penetration of chlorine ions from corrosive media to the surface of metal and thus reduces corrosion rates. Estimated, laboratory and comparison passivation coefficients have been proposed. These coefficients make it possible to predict the level of steel self-passivation with regard to operating conditions of particular oilfields.
\end{abstract}

\section{Introduction}

The use of seamless drawn oil/gas line pipes manufactured from low-carbon chromium 13KhFA and 08KhMFChA steels has significantly improved the service ability of pipeline transportation systems used in the oil industry $[1,2]$. The manufacturing of welded pipes from these steels has also been mastered. In comparison with seamless drawn pipes, they are cheaper, have more stable dimensions and better resistance to corrosion of their internal surface. These advantages transform into benefits, if their base metal and weldments have similar mechanical properties and corrosion behaviour while demonstrating identical changes during their operation. However, the issue of using welded pipes in oilfields with highly corrosive media still persists. The kinetics of the self-passivation of steels with contents of chromium in carbon dioxide media also needs further investigation. The most effective understanding of these matters can be achieved through long-duration field tests. The purpose of this paper is to obtain information on the mechanism and kinetics of the development of corrosion attack/mechanical fracture in welded pipes in the course of their operation in highly corrosive oilfield media.

\section{Objects and methods of tests and investigations}

\subsection{Objects of the investigations}

The tests were carried out on longitudinally electricwelded pipes $(\varnothing 219 \times 8 \mathrm{~mm})$ manufactured from 08KhMFChA (Steel 1), 08KhMFChA (Steel 2), 13KhFA, 20-ksh (steel 20 corrosion resistant cold resistant) and grade steel 20 (the chemical composition is show in the table). Promising steels (08KhMFChA and 13KhFA) were selected, as well as traditional steels (20 and 20ksh) for comparison. Two heats of Steel 08KhMFChA differ in the weight of cerium-containing wire added to the ladle: Steel1-150 kg and Steel 2-250 kg. However, positive material identification results showed that the contents of cerium consumed by these heats are identical and range 37 to $49 \mathrm{ppm}$. Chemical composition of the steels under investigation is presented in Table 1.

Table 1. Chemical composition of the steels under investigation.

\begin{tabular}{|c|c|c|c|c|c|c|}
\hline \multicolumn{2}{|c|}{ Steel Grade } & $13 \mathrm{KhFA}$ & 08KhMFChA & 08KhMFChA & 20-ksh & grade st20 \\
\hline \multirow{15}{*}{$\begin{array}{c}\text { Weight } \\
\text { percentages of } \\
\text { the elements, } \\
\text { present }\end{array}$} & $\mathrm{C}$ & 0,09 & 0,07 & 0,07 & 0,21 & 0,21 \\
\hline & $\mathrm{Si}$ & 0,35 & 0,34 & 0,35 & 0,26 & 0,24 \\
\hline & $\mathrm{Mn}$ & 0,54 & 0,53 & 0,52 & 0,55 & 0,42 \\
\hline & $P$ & 0,01 & 0,005 & 0,005 & - & 0,001 \\
\hline & $\mathrm{S}$ & 0,002 & 0,001 & 0,001 & 0,006 & 0,004 \\
\hline & $\mathrm{Cr}$ & 0,57 & 0,66 & 0,66 & 0,02 & 0,03 \\
\hline & Mo & 0,002 & 0,131 & 0,125 & 0,003 & 0,003 \\
\hline & $\mathrm{Ni}$ & 0,002 & 0,16 & 0,16 & 0,03 & 0,04 \\
\hline & $\mathrm{Al}$ & 0,034 & 0,038 & 0,036 & 0,025 & 0,037 \\
\hline & $\mathrm{Cu}$ & 0,03 & 0,14 & 0,15 & 0,05 & 0,04 \\
\hline & $\mathrm{N}$ & 0,004 & 0,003 & 0,004 & 0,007 & 0,007 \\
\hline & $\mathrm{Nb}$ & 0,018 & 0,029 & 0,028 & 0,04 & 0,001 \\
\hline & $\mathrm{Ti}$ & 0,004 & 0,003 & 0,002 & 0,002 & 0,002 \\
\hline & V & 0,046 & 0,063 & 0,063 & 0,001 & 0,002 \\
\hline & $\mathrm{Ca}$ & 0,001 & 0,002 & 0,002 & $<0,0005$ & $<0,0005$ \\
\hline
\end{tabular}


The pipes were manufactured by the Vyksa Metallurgical Plant in the regular process with local thermal treatment of the weld followed by $3 \mathrm{D}$ thermal treatment of the pipes (normalizing). The metal of the pipes is uniform throughout the thickness of the wall and features the ferritic-pearlite structure. Banded orientation was not revealed. The cementite component of pearlite has a plate like shape.

\section{Methods of testing}

Bypass pilot testing was carried out in conditions most similar to operating ones. A bypass line parallel to the oilgathering line was built at the chosen oilfield of Stavropolneftegaz LLC. It is made from $1000 \mathrm{~mm}$ long, $\varnothing 219 \times 8 \mathrm{~mm}$ fitting pipes cut from the pipes being tested. Operating conditions and physical/chemical characteristics of the carried medium in the oil-gathering line are presented in Tables 2 and 3. High salinity, high watercut, high temperature and increased contents of dissolved gases $\left(\mathrm{H}_{2} \mathrm{~S}, \mathrm{CO}_{2}, \mathrm{Cl}^{-}\right)$have determined the high corrosiveness of oilfield media and the severe conditions of the tests. The tests were carried out in several stages: for Steel 13KhFA the test duration was 7, 15, 17 and 23 months, for Steels 08KhMFChA №1 and №2 it was 9 and 23 months, and for Steels $20-\mathrm{ksh}$ and 20 it was 9 months.

Table 2. Operating conditions in the oil-gathering line $\varnothing 219 \times 8$ $\mathrm{mm}$ GU-2, GU -5 .

\begin{tabular}{|c|c|c|c|c|c|c|}
\hline $\begin{array}{c}\text { Operational } \\
\text { pressure }\end{array}$ & $\begin{array}{c}\text { Liquid } \\
\text { volume }\end{array}$ & Watercut & $\begin{array}{c}\text { Sulphate reducing } \\
\text { bacteria } \\
\text { (plankton) }\end{array}$ & Density & $\begin{array}{c}\text { Gas input } \\
\text { factor }\end{array}$ & $\begin{array}{c}\text { Mean } \\
\text { temperature }\end{array}$ \\
\hline atmosph & $\mathrm{m} 3 /$ day & per cent & cells/mL & $\mathrm{t} / \mathrm{cm} 3$ & $\mathrm{~m} 3 / \mathrm{t}$ & ${ }^{\circ} \mathrm{C}$ \\
\hline 10 & 898.5 & 94 & 102 & 0.825 & 111.8 & $70 \div 80$ \\
\hline
\end{tabular}

Table 3. Physical and chemical characteristics of the carried medium.

\begin{tabular}{|c|c|c|c|c|c|c|c|c|c|c|}
\hline \multirow{2}{*}{$\mathrm{H}_{2} \mathrm{~S}$} & \multirow{2}{*}{$\mathrm{CO}_{2}$} & \multirow{3}{*}{$\mathrm{Fe}$} & \multirow{3}{*}{$\mathrm{pH}$} & \multirow{2}{*}{$\begin{array}{l}\text { General } \\
\text { salinity }\end{array}$} & \multicolumn{6}{|c|}{ Ion composition, $\mathrm{g} / \mathrm{L}$} \\
\hline & & & & & $\mathrm{HCO}_{3}^{-}$ & $\mathrm{SO}_{42} 2^{-}$ & $\mathrm{Cl}^{-}$ & $\mathrm{Ca}^{2+}$ & $\mathrm{Mg}^{2+}$ & $\begin{array}{c}\mathrm{Na}^{+}+ \\
\mathrm{K}^{+}\end{array}$ \\
\hline \multicolumn{2}{|c|}{$\mathrm{mg} / \mathrm{L}$} & & & \multicolumn{7}{|c|}{$\mathrm{g} / \mathrm{L}$} \\
\hline 5 & 179 & 29 & 6.5 & 83.44 & 0.28 & 5.13 & 45.49 & 2.78 & 0.26 & 29.50 \\
\hline \multicolumn{11}{|c|}{$\begin{array}{l}\text { Note. - The employed method of quantifying } \mathrm{CO}_{2} \text { and } \mathrm{H}_{2} \mathrm{~S} \text { dissolved in the medium does } \\
\text { not exclude degassing; hence, the actual contents of these corrosive components in the } \\
\text { pipeline may be considerably higher than the above figures. }\end{array}$} \\
\hline
\end{tabular}

On completion of the bypass pilot testing stage, individual fitting pipes were selected or the entire line was dismantled following the completion of work. The fitting pipes were cut into characteristic sections, cleaned of crude products, and specimens for investigation were prepared. A specially developed integrated methodology [3] was employed to investigate the changing properties and the effects of corrosion on the pipes in course of their operation. The method includes investigation into the mechanical properties and corrosion behaviour of the base metal and welded joints of the pipes, into the mechanism and kinetics of corrosion damage, as well as into the composition and structure of the metal and corrosion products. The following methods were used for the above purposes:
- metallographic examination of the surface, crosssections and points of fracture;

- visible light microscopy - the Olympus GX51 microscope;

- electron microscopy - the Philips XL-30 microscope;

- mechanical testing: the uniaxial tension test to GOST 1497-78 and the impact test to GOST 9454-78;

- corrosion resistance testing: the HIC cracking test to NACE TMO284, the sulfide stress corrosion cracking test to NACE TMO177, Methods A and D), the general corrosion test (methodology developed by «NefteGazService» Research and Production Centre);

- defining general and local corrosion rates in the course of the test by the wall thickness losses and by the size of pits;

- defining the fluid content of corrosion products by means of the Drone-2 X-ray diffractometer;

- defining the structure and chemical composition of corrosion products by means of the XL-30 scanning electron microscope with the Edax energy dispersive analyzer;

- microbiological tests for adhesive forms of corrosive bacteria of the oilfield bacterial community to NACE TM 0194-2004, and NACE TM 0106-2006.

\section{Discussion of test results}

\subsection{General and local corrosion of pipes}

Corrosion-related failure rates of welded joints and base metal at the bottom and in the other areas of the pipe are practically the same, which makes it possible to restrict corrosion testing to general and local (pitting) corrosion. General corrosion rate is determined by the thinning of the pipe wall, whereas local corrosion rate is determined by the depth of the pits. Measurements were carried out after each stage of the tests on all of the pipes manufactured from the steel grades under investigation. The obtained results are presented in Tables 4 and 5 . Four stages of gradually increasing duration $(7,15,17$, and 23 months) for Steel 13KhFA and two stages of the test ( 9 and 23 months) for Steel 08KhMFChA provided information on corrosion rate changes versus time in service (Fig. 1), i.e., on the ongoing process of selfpassivation.

A period of steady-state corrosion attack settles in the course of the testing ( 7 to 23 months) which is determined by the intensity of two interrelated processes: the dissolving of the metal in the corrosive medium and the protective effect of corrosion products. As a first approximation, linear dependence on time can be assumed for the period, as per the expression $y=0.65$ $-0.11 \mathrm{x}$ (solid line in Fig. 1). Earlier field tests of $13 \mathrm{KhFA}$ and $08 \mathrm{KhMFChA}$ welded pipes (two stages of 8 and 14 months) that had been carried out at one of the West Siberia oilfields with similar aggressive agent $\left(\mathrm{CO}_{2}, \mathrm{H}_{2} \mathrm{~S}\right.$ and $\left.\mathrm{Cl}^{-}\right)$contents in the oilfield medium, demonstrated similar results in terms of resistance to corrosion. They are marked by (*) and (x) in Fig. 1. 


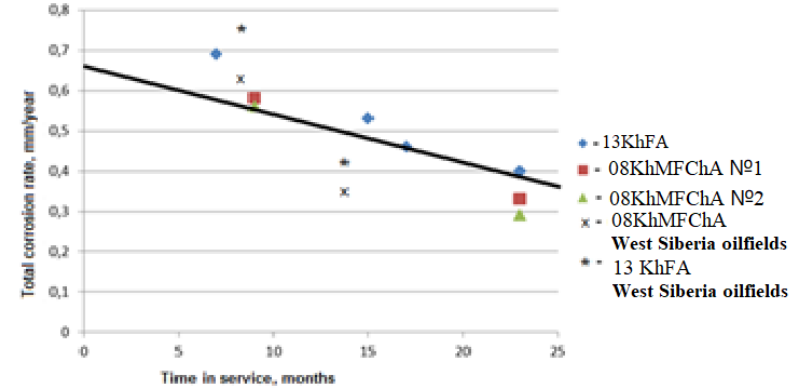

Fig. 1. Total corrosion rates versus time in service.

Table 4. Corrosion rates versus time in service for $13 \mathrm{KhFA}$ pipes.

\begin{tabular}{|c|c|c|c|c|c|c|c|c|}
\hline \multirow{3}{*}{ Steel grade } & \multicolumn{4}{|c|}{$\begin{array}{l}\text { Corrosion rate in the course of the test, } \\
\mathrm{mm} / \text { year }\end{array}$} & \multicolumn{4}{|c|}{ Process parameters } \\
\hline & \multirow{2}{*}{\multicolumn{4}{|c|}{ 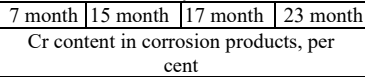 }} & \multirow{3}{*}{$\begin{array}{l}\mathrm{Kw} \\
7-23 \\
\text { month }\end{array}$} & \multirow{3}{*}{$\begin{array}{l}\mathrm{Kw} \\
15-23 \\
\text { month }\end{array}$} & \multirow{3}{*}{ Kp.com } & \multirow{3}{*}{ Kp.ex. } \\
\hline & & & & & & & & \\
\hline \multirow{7}{*}{$13 \mathrm{KhFA}$} & 2.5 & 2.7 & 4.5 & 4.0 & & & & \\
\hline & \multicolumn{8}{|c|}{ General corrosion } \\
\hline & 0.25 & 0.22 & 0.15 & 0.18 & -0.12 & -0.34 & 1.4 & 4.8 \\
\hline & \multicolumn{8}{|c|}{ Local (pitting) corrosion } \\
\hline & 0.44 & 0.31 & 0.31 & 0.22 & -0.22 & -0.54 & 1.7 & 2.7 \\
\hline & \multicolumn{8}{|c|}{ Total corrosion (local + general) } \\
\hline & 0.69 & 0.53 & 0.46 & 0.40 & -0.31 & -0.46 & 1.3 & 1.7 \\
\hline
\end{tabular}

Table 5. Corrosion rates versus time in service of 08KhMFChA, 20-ksh and grade st.20 pipes.

\begin{tabular}{|c|c|c|c|c|c|c|c|c|c|c|c|c|}
\hline \multirow{4}{*}{ Steel grade } & \multicolumn{5}{|c|}{ General corrosion } & \multicolumn{5}{|c|}{$\begin{array}{cc}\begin{array}{c}\text { Total corrosion } \\
\text { general) }\end{array} & \text { local + } \\
\end{array}$} & \multirow{2}{*}{\multicolumn{2}{|c|}{$\begin{array}{c}\text { Cr content in } \\
\text { corrosion } \\
\text { products, per } \\
\text { cent }\end{array}$}} \\
\hline & \multirow{2}{*}{\multicolumn{2}{|c|}{$\begin{array}{c}\text { Corrosion rate } \\
\mathrm{mm} / \text { year }\end{array}$}} & \multirow{2}{*}{\multicolumn{3}{|c|}{$\begin{array}{l}\text { Process } \\
\text { parameters }\end{array}$}} & \multirow{2}{*}{\multicolumn{2}{|c|}{$\begin{array}{c}\text { Corrosion rate } \\
\mathrm{mm} / \mathrm{year}\end{array}$}} & \multirow{2}{*}{\multicolumn{3}{|c|}{$\begin{array}{c}\text { Process } \\
\text { parameters }\end{array}$}} & & \\
\hline & & & & & & & & & & & & \\
\hline & \begin{tabular}{|c|}
9 \\
month \\
\end{tabular} & \begin{tabular}{|c|}
23 \\
month
\end{tabular} & $\mathrm{Kw}$ & & \begin{tabular}{|c|} 
Kp.e \\
X \\
\end{tabular} & \begin{tabular}{|c|}
9 \\
month \\
\end{tabular} & \begin{tabular}{|c|}
23 \\
month
\end{tabular} & $\mathrm{Kw}$ & \begin{tabular}{|c|} 
Kp.c \\
om
\end{tabular} & $\begin{array}{c}\text { Kp.e } \\
\text { x. }\end{array}$ & $\begin{array}{c}9 \\
9 \\
\text { month }\end{array}$ & \begin{tabular}{c|}
23 \\
month
\end{tabular} \\
\hline $\begin{array}{c}\text { 08KhMFChA } \\
\text { №1 }\end{array}$ & 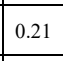 & 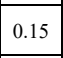 & -0.18 & 1. & 4.7 & 0.58 & 0.33 & $-0.28 \mid$ & 1.5 & 1.7 & 3.75 & 4.8 \\
\hline $\begin{array}{c}08 \mathrm{KhMFChA} \\
\text { №2 } \\
\end{array}$ & 0.23 & 0.13 & -0.28 & 1.5 & 4.3 & 0.56 & 0.29 & -0.31 & 1.6 & 1.8 & 3.6 & 4. \\
\hline 20-ksh & 28 & & 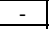 & 1.3 & \begin{tabular}{|l|l|}
10.7 \\
\end{tabular} & 0.83 & - & - & 1,07 & 3.6 & 0.11 & \\
\hline irade Steel 20 & 0.36 & & -5 & - & 9.1 & \begin{tabular}{l|l}
0.89 \\
\end{tabular} & - & - & - & 3.7 & 0.07 & \\
\hline
\end{tabular}

\subsection{Structure and composition of corrosion products}

As per the results of the analyses that have been carried out, corrosion products are multiphase with contents of oxides, hydroxides, carbonates, chlorides and sulfides of iron, the phases of the metal which are neutral in a corrosive medium; they comprise chemical compounds of alloying elements with components of the medium, as well as mechanical mixtures of these phases. This composition of corrosion products is typical of the steels operating in carbon dioxide media with increased contents of $\mathrm{H}_{2} \mathrm{~S}$ and Cl- [4-6]. The main component of these corrosion products is ferric carbonate $\mathrm{FeCO}_{3}$ that forms a solid layer. The thickness of the layer, its composition and properties change in the course of operation. Resistance of steels to corrosion depends on the following characteristics of the layer: cohesion, adhesion to the metal, and its ability to isolate the metal from the corrosive medium.

It is well known that resistance of steels to carbon dioxide corrosion increases along with an increase in chromium content. This relationship is close to linear dependence within the 5 per cent $\mathrm{Cr}$ content $[2,7]$. In corrosion products, chromium is in amorphous phase form $\mathrm{Cr}(\mathrm{OH})_{3}$. The amount of chromium in corrosion products may be 3-10 times as high as that in the steel [7-9].

As per the results of the analyses, the presence of the phase with chromium content largely determines the possibility of exposure of metal surface to chlorine ions. This exposure intensifies the process of corrosion attack. After the test, Cl- in 08KhMFChA (Steel 1) is blocked by the carbonate layer (Figure 2a), whereas in Steel 20ksh (table 1), which has no chromium content, chlorine from the corrosive medium finds its way through corrosion products and accumulates on the surface of the metal (Fig. 2b).

In steels, chromium may be in two different forms: as a component of special carbides or as solid solution. These forms have different impacts on mechanical properties and corrosion processes. Therefore, corrosion rate figures and their change in course of time should be related to chromium content in corrosion products, rather than to total chromium content in the steel. The amount of chromium in corrosion products was quantified on microsections by layer-to layer semi quantitative X-ray spectrum analysis. The measurements were taken through 0.5-1 percent of the layer thickness, which amounted to 120 horizontal lines and 50 measurements per line. The mean chromium content figures for the most saturated layer are presented in Tables 4 and 5, while their dependence on the time in service is shown in Fig. 3. As per the supposedly linear relationship, the dependence is presented in the expression $\mathrm{y}=2.5+0.082 \mathrm{x}$ (solid line) which corresponds to the steady process of corrosion attack development. The section illustrating the duration of 5 months (broken curved line) corresponds to the early accelerated development of the process.

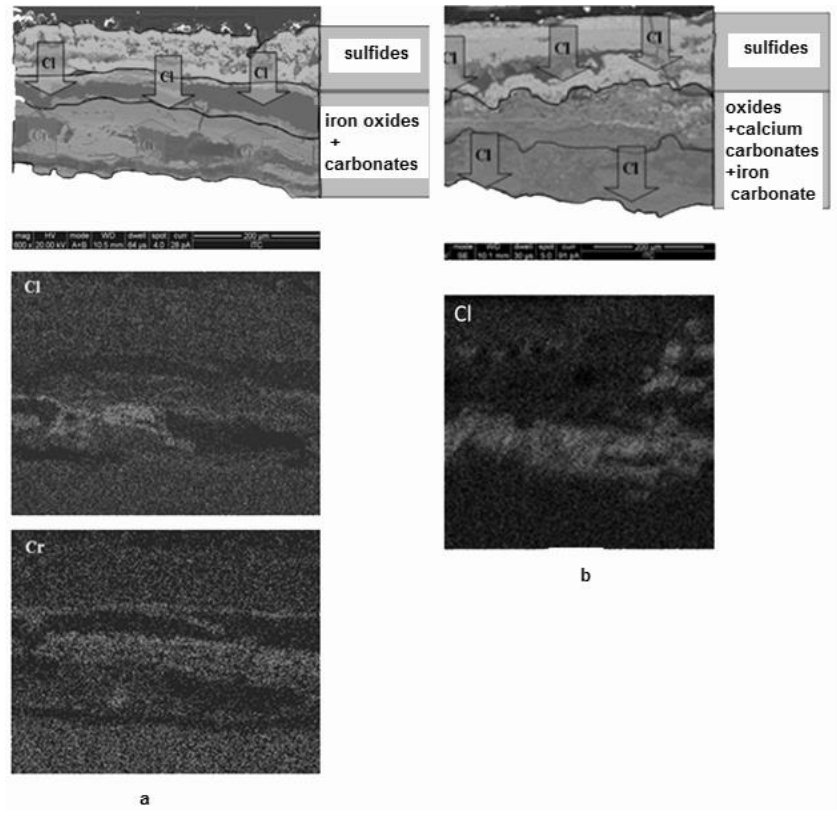

Fig. 2. Structure and chemical composition under characteristic xeroradiography of corrosion products on the internal surface of Ø 219x8 mm pipes after 9 months in service: a) 08KhMFChA (Steel 1); b) Steel 20-ksh. 


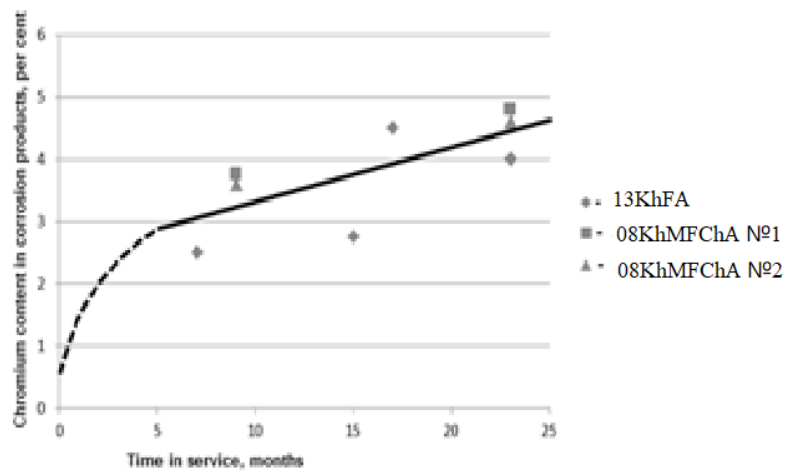

Fig. 3. Chromium content in corrosion products versus time in service.

After revealing the dependence of corrosion rates and chromium content in corrosion products on time in service (Fig. 1 and 3) it is perfectly logical to move on to analyzing the dependence of corrosion rate on chromium content in corrosion products (Fig. 4) which is also presented in linear form $y=0,89-0,11 x$ (solid line).

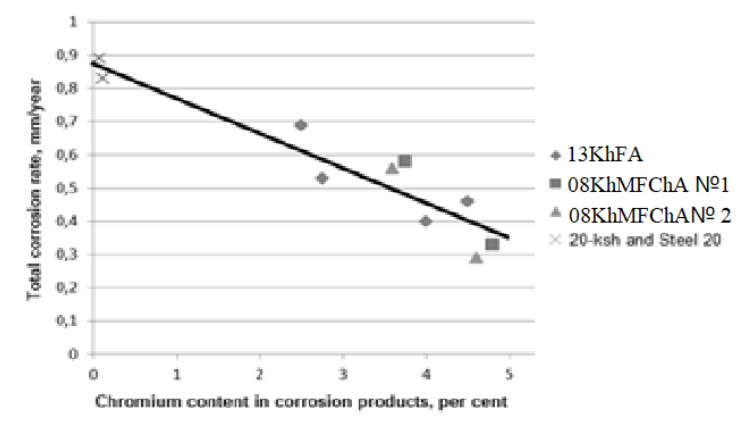

Fig. 4. Corrosion rate versus chromium content in corrosion products.

Obviously, linear dependence cannot completely describe the complicated process of the development of self-passivation. It is characteristic only of the investigated time in service ( 7 to 23 months) and corresponds to the process of steady corrosion attack.

\subsection{In-service changes in mechanical properties of pipes}

Time in service and specific operating conditions (hydrogen charging, vibration, cyclic deformation, natural aging and others) may cause numerous defects which affect mechanical properties; in particular, they may lead to a decrease in plasticity. The properties of the base metal and welded joint of Steels 13KhFA and 08KhMFChA were measured and subsequently compared before and after each stage of the testing process for the purpose of evaluating the ongoing changes (Table 6). It can be seen that strength, plasticity and impact strength of the base metal and welded joints of the pipes practically did not change in course of the two years' time in service.
Table 6. Changes of welded pipes' mechanical properties $\varnothing$ $219 \times 8 \mathrm{~mm}$ in course of time in service.

\begin{tabular}{|c|c|c|c|c|c|}
\hline \multirow[t]{2}{*}{$\begin{array}{c}\text { Steel grade } \\
\text { (inoculant } \\
\text { type, batch, } \\
\text { heat) }\end{array}$} & \multirow[t]{2}{*}{$\begin{array}{c}\text { Point of } \\
\text { cutting } \\
\text { specimens }\end{array}$} & \multirow[t]{2}{*}{ Testing stage } & \multicolumn{2}{|c|}{$\begin{array}{l}\text { Impact bend (KCV), } \\
\mathrm{kgcm} / \mathrm{cm} 2 \\
\text { At test temperature } \\
\text { (the proportion of the } \\
\text { ductile component in } \\
\text { theattack) }\end{array}$} & \multirow[t]{2}{*}{$\begin{array}{r}\text { Uniaxial } \\
\text { tension } \\
\kappa \mathrm{\kappa} / \mathrm{mm} 2 \\
\sigma \mathrm{B} \\
\end{array}$} \\
\hline & & & $-40^{\circ} \mathrm{C}$ & $-50^{\circ} \mathrm{C}$ & \\
\hline \multirow{8}{*}{$13 \mathrm{KhFA}$} & \multirow{3}{*}{$\begin{array}{l}\text { Welding } \\
\text { seam, } \\
\text { longitudi } \\
\text { nal }\end{array}$} & Receipt control & $\begin{array}{c}28,8 \\
(100)\end{array}$ & - & 53,2 \\
\hline & & $\begin{array}{l}\text { After } 15 \text { months } \\
\text { pilot tests }\end{array}$ & $\begin{array}{c}28,5 \\
(100)\end{array}$ & - & 54,1 \\
\hline & & $\begin{array}{l}\text { After } 23 \text { months } \\
\text { pilot tests }\end{array}$ & $\begin{array}{c}27,9 \\
(100)\end{array}$ & - & 54,6 \\
\hline & \multirow{5}{*}{$\begin{array}{c}\text { Base } \\
\text { metal, } \\
\text { transvers } \\
\mathrm{e}\end{array}$} & Receipt control & $\begin{array}{c}24,7 \\
(100)\end{array}$ & $\begin{array}{c}22,5 \\
(100)\end{array}$ & 59,2 \\
\hline & & $\begin{array}{c}\text { After } 7 \text { months } \\
\text { pilot tests }\end{array}$ & $\begin{array}{l}23,1 \\
(100) \\
\end{array}$ & $\begin{array}{l}21,3 \\
(100) \\
\end{array}$ & 57,7 \\
\hline & & $\begin{array}{l}\text { After } 17 \text { months } \\
\text { pilot tests }\end{array}$ & $\begin{array}{l}21,0 \\
(100)\end{array}$ & $\begin{array}{l}20,6 \\
(100)\end{array}$ & 58,4 \\
\hline & & $\begin{array}{l}\text { After } 15 \text { months } \\
\text { pilot tests }\end{array}$ & $\begin{array}{l}20,8 \\
(100)\end{array}$ & $\begin{array}{l}20,0 \\
(100)\end{array}$ & 57,3 \\
\hline & & $\begin{array}{l}\text { After } 23 \text { months } \\
\text { pilot tests }\end{array}$ & $\begin{array}{c}21,7 \\
(100)\end{array}$ & $\begin{array}{c}22,8 \\
(100)\end{array}$ & 58,1 \\
\hline \multicolumn{3}{|c|}{$\begin{array}{l}\text { Standard requirements } 1383-010-48124013-03 \text { as } \\
\text { to K52 pipes }\end{array}$} & $\begin{array}{l}\geq 8 \\
(50)\end{array}$ & - & $\geq 52$ \\
\hline \multirow{5}{*}{$\begin{array}{l}\text { 08KhMFChA } \\
\quad \text { №1 }\end{array}$} & \multirow{2}{*}{$\begin{array}{l}\text { Welding } \\
\text { seam, } \\
\text { longitudi } \\
\text { nal }\end{array}$} & Receipt control & - & $\begin{array}{l}29,0 \\
(100)\end{array}$ & 59,3 \\
\hline & & $\begin{array}{l}\text { After } 23 \text { months } \\
\text { pilot tests }\end{array}$ & - & $\begin{array}{l}28,7 \\
(100) \\
\end{array}$ & 58,4 \\
\hline & \multirow{3}{*}{$\begin{array}{c}\text { Base } \\
\text { metal, } \\
\text { transvers } \\
\mathrm{e}\end{array}$} & Receipt control & $\begin{array}{l}26,0 \\
(100)\end{array}$ & $\begin{array}{l}25,9 \\
(100)\end{array}$ & 60,9 \\
\hline & & $\begin{array}{l}\text { After } 9 \text { months } \\
\text { pilot tests }\end{array}$ & $\begin{array}{c}26,9 \\
(100)\end{array}$ & $\begin{array}{c}25,8 \\
(100)\end{array}$ & 59,5 \\
\hline & & $\begin{array}{c}\text { After } 23 \text { months } \\
\text { pilot tests }\end{array}$ & $\begin{array}{r}25,9 \\
(100) \\
\end{array}$ & $\begin{array}{l}26,5 \\
(100) \\
\end{array}$ & 59,8 \\
\hline \multirow{5}{*}{$\begin{array}{l}\text { 08KhMFChA } \\
\quad \text { №2 }\end{array}$} & \multirow{2}{*}{$\begin{array}{l}\text { Welding } \\
\text { seam, } \\
\text { longitudi } \\
\text { nal }\end{array}$} & Receipt control & - & $\begin{array}{l}27,8 \\
(100) \\
\end{array}$ & 59,1 \\
\hline & & $\begin{array}{c}\text { After } 23 \text { months } \\
\text { pilot tests }\end{array}$ & - & $\begin{array}{c}28,2 \\
(100)\end{array}$ & 59,2 \\
\hline & \multirow{3}{*}{$\begin{array}{c}\text { Base } \\
\text { metal, } \\
\text { transvers } \\
\mathrm{e}\end{array}$} & Receipt control & $\begin{array}{c}26,9 \\
(100)\end{array}$ & $\begin{array}{c}26,8 \\
(100)\end{array}$ & 59,2 \\
\hline & & $\begin{array}{l}\text { After } 9 \text { months } \\
\text { pilot tests }\end{array}$ & $\begin{array}{c}25,2 \\
(100)\end{array}$ & $\begin{array}{l}26,0 \\
(100)\end{array}$ & 58,9 \\
\hline & & $\begin{array}{l}\text { After } 23 \text { months } \\
\text { pilot tests }\end{array}$ & $\begin{array}{l}26,5 \\
(100)\end{array}$ & $\begin{array}{l}27,0 \\
(100)\end{array}$ & 57,3 \\
\hline \multicolumn{3}{|c|}{$\begin{array}{l}\text { Standard requirements } 1303-006.3-593377520-03 \\
\text { as to K52 pipes }\end{array}$} & - & $\geq 6(50)$ & $\geq 52$ \\
\hline
\end{tabular}

\section{Evaluating in-service self-passivation}

Along with a number of requirements concerned with mechanical properties and corrosion behaviour, one of the other important characteristics of steels used for manufacturing oilfield pipes is their ability of selfpassivation in the working fluid, i.e., to reduce the intensity of corrosion attack in the course of operation. It is the self-passivation ability that in many respects determines pipeline systems' ability to operate safely. It should be made part of technical documentation that defines the properties of steel.

The variety of processes occurring at the metalmedium interface, the complexity of their interaction, and the uncertainty of their transformation in course of time do not let us hope for the development of a theory describing the initiation and propagation of corrosion attack. It is the results of regular measurements of corrosion rates during laboratory or oilfield tests that make the source of information.

The presumed self-passivation level of the steel under investigation in corrosive medium may be evaluated on the basis of three comparative selfpassivation coefficients. The coefficients represent the ratio of estimated corrosion rates measured in laboratory 
tests on specimens to corrosion rate values of the steel under investigation (Vi.s.) obtained in oilfield tests. Time slot between measurements of Vi.s. should provide recognition of a steady corrosion process.

1. Estimated coefficient of self-passivation $\left(K_{p}\right.$.est $)$

$$
K_{\mathrm{p} . \text { est. }}=\mathrm{V}_{\mathrm{p}} / \mathrm{V}_{\text {i.s. }},
$$

where $\mathrm{Vp}$ is dioxide corrosion rate calculated by the De Wards - Millams formula [9], with temperature and pressure values adjusted to oilfield conditions [10]. The impact of corrosion products is not considered by the formula representing the rate at which iron dissolves in the carbon dioxide medium. The effectiveness of the use of the estimated self-passivation coefficient depends on the precision of measurements of $\mathrm{CO}_{2}$ partial pressure in the working fluid.

2. Experimental coefficient of self-passivation ( $\left.\mathrm{K}_{\text {p.ex. }}\right)$

$$
K_{\text {p.ex. }}=V_{l, I} / V_{\text {i.s. }},
$$

where $\mathrm{V}_{1, \mathrm{i}}$ the carbon dioxide corrosion rate measured in laboratory tests, $\mathrm{K}_{\mathrm{p} \text {.ex }}$ characterizes the difference in corrosion rates during laboratory tests and oilfield tests. Laboratory $\mathrm{CO}_{2}$ corrosion resistance tests are characterized by shorter duration and severer conditions compared to oilfield tests. Corrosion products do not form because their formation needs longer times; hence, they do not protect the metal. This is why corrosion rates are different in laboratory and oilfield tests. At present, there is no generally accepted methodology for laboratory testing. We employed the methods described in [11]. V1,i. values were defined at the temperature of $60^{\circ} \mathrm{C}$ and curing time of 120 hours. The values were found for the following steels: $13 \mathrm{KhFA}-1.2 \mathrm{~mm} /$ year, $08 \mathrm{KhMFChA}-$ 1,0 mm/year; 20-ksh - $3.0 \mathrm{~mm} /$ year; Grade St. $20-3.3$ $\mathrm{mm} /$ year; 09MnSiN - $2.7 \mathrm{~mm} /$ year. Kp.ex. values were calculated on the basis of the above data. They are presented in Tables 4 and 5.

3. Comparison self-passivation coefficient $\left(K_{\text {p.com. }}\right)$

$$
K_{\text {p.com. }}=V_{\text {o.c. }} / V_{\text {i.s. }}
$$

where Vo.c. is the reference specimen corrosion rate measured in one oilfield experiment in conditions identical to those of the steel under investigation. Typical pipe Steel 20 without special alloying elements is normally used for comparison. The obtained values of Kp.com are presented in Tables 4, 5.

The coefficients Kp.est, Kp.ex and Kp.com. provide estimated and comparison values of self-passivation of the steel under investigation. Values of the quantity of selfpassivation in operating conditions may be obtained through the known dependence of corrosion rate on test duration.

In the absence of analytical dependence, some understanding of the intensity of the passivation process may be obtained on the basis of the results of oilfield tests by using the coefficient of relative change of corrosion rate during relative change of $(\mathrm{Kw})$ :

$$
K w=K v / K t,
$$

where $\mathrm{Kv}=(\mathrm{Vn}-\mathrm{V} 1) / \mathrm{V} 1$ is the relative change of corrosion rate, $\mathrm{K} \mathrm{t}=(\mathrm{tn}-\mathrm{t} 1) / \mathrm{t} 1$ is the relative change of time in service, $\mathrm{V} 1$ and $\mathrm{Vn}$ are corrosion rates during the 1 st test stage and the nth test stage respectively.

The negative value of $\mathrm{Kw}$ means that corrosion stifles in the course of service, whereas self-passivation of the metal prevails.

$\mathrm{Kw}$ values for the steel under investigation are calculated and presented in Tables 4 and 5. These values prove the intensity of self-passivation of chromiumcontaining steels $13 \mathrm{KhFA}$ and $08 \mathrm{KhMFChA}$ during operation.

\section{Conclusions}

1. Mechanical properties of the base metal and welded joints of pipes manufactured from steels 13KhFA and 08KhMFChA have practically not changed during their time in service (two years).

2. The formation of chromium-containing phase in corrosion products inhibits ions of chlorine and prevents them penetrating from the corrosive medium to the surface of metal and thereby reduces corrosion rate.

3. The dependences experimentally obtained in the course of long-duration oilfield tests (time in service corrosion rate; time in service - chromium content in corrosion products; and chromium content in corrosion products - corrosion rate) make it possible to evaluate the impact of chromium on the development of selfpassivation of steels in oilfield carbon dioxide media. 4. Three coefficients (estimated coefficient, laboratory coefficient and comparison coefficient) have been proposed that make it possible to predict the level of self-passivation of steels during their time in service in oilfields with media of particular composition.

\section{References}

1. V.V. Zavyalov, VNIIO-ENG, (2005)

2. M.A. Vyboischik, A. Ioffe, Advanced materials. T.7, (2017)

3. Methodology «Carrying out field tests of pipeline fittings of oil/gas pipelines in actual crude oil pipeline conditions», Samara: IT-Service, (2012)

4. Y. Choy, S Nesic, S. Electrochimica Acta, Vol.56. №4, (2011)

5. J. Sun, C. Sun, X. Lin, X. Cheng, H. Liu, Materials, Vol.9. №3, (2016)

6. D.P Li., L. Zhang, J.W. Yang, M. X. Lu, J.-H. Ding, M.L. Liu, Metallurgy and Materials, Vol.21. №4, (2014)

7. A.V Ioffe., M.A Vyboishchik., E.A. Trifonova, P.V. Suvorov, Metal Science and Heat Treatment, Vol.52, Iss.1, (2010)

8. S. Guo, L. Xu, L. Zhang, W. Chang, M. Lu, Corrosion Science, Vol.63, (2012) 
9. M. Ko, B. Ingham, N. Laycock, Corrosion Science, Vol.80, (2014)

10. C.de Waard, D.E Milliams, Corrosion, V.31, №5, (1975)

11. A.N. Markin, R.E. Nizamov, JSC VNIIOENG, (2003)

12. Methodology №004-2009, Evaluating general corrosion rate in the model $\mathrm{CO} 2$-containing medium, Samara: IT-service, (2013) 